\title{
Salt Lake City: Libraries to visit
}

\author{
By Blaine H. Hall \\ Humanities Librarian \\ Brigham Young University
}

\section{Genealogy, cowboy poetry, and Cecil B. DeMille are only a few of the interesting subjects you'll find in the SLC libraries.}

$\mathrm{W}$ hile you're in Salt Lake City at the ACRL Sixth National Conference in April 1992 take the opportunity to visit some of the libraries in the area. Organized tours are planned for the Latter Day Saints (LDS) Family History Library and the University of Utah libraries, and other academic libraries will welcome any visitors who wish to visit them on their own.

\section{Family History Library}

Unique to Salt Lake City is the world's largest repository of genealogical information, the Family History Library of the LDS Church with over 1.8 million rolls of microfilm (equal to about 6 million written volumes), 320,000 microfiche, over 225,000 bound volumes, and $9,000,000$ family group sheets. And its collection grows by over 1.5 million rolls per year, the output from over 200 cameras filming birth, marriage, death, probate, immigration, military, census, and many other genealogically important records in 45 countries. Most of the records date from about 1550 to 1910 , with few records of living persons. The book collection includes published family histories, local histories, indexes, periodicals, and other research aids.

The filming projects photograph the records kept by governments, churches, archives, and other organizations and not only provide records for the library's collections, but also provide a copy of the film for the organization that gave permission for the filming. An original preservation copy of each film is kept in the Granite Mountain Records Vault in a canyon southeast of the city where they are safe from flood, fire, earthquake, and other disasters.
This great resource is available free of charge for public use. Its users come from all over the world and include historians, sociologists, medical researchers, and others seeking information about missing heirs, adoptions, and many other purposes.

The library provides several important computerized catalogs and indexes that readily make its vast collections available to users. The Family History Library Catalog lists and describes the library records and gives the film and book numbers needed to find items. The International Genealogical Index lists the birth, christening, marriage, and other dates of more than 147 million deceased persons. The Ancestral File links individuals into families and pedigrees. Searching the 10 million names in this file will show you if anyone has already submitted information about your family. You will then be able to make paper or diskette copies of the families and pedigrees you find. You too can submit your family information to the Ancestral File and share your work with others.

The group tour of the library will include an orientation slide show, a demonstration of the library's electronic catalog and genealogical indexes, and a discussion of basic genealogical research principles. If you want to try an ancestral search of your own while you are here, be sure to bring the names, locations, and approximate dates of births, christenings, marriages, and funerals. Staff and volunteers will be glad to help you.

\section{University libraries}

At Utah's university libraries visitors will find major research collections of books, manuscripts, 
photographs, glass slide negatives, sound recordings, etc. on Mormonism, Utah, the West, and many other specialized subjects. The Merrill Library at Utah State University in Logan (a 90-minute drive north) has outstanding collections on Jack London, Water and the West, and the Fife Folklore Archive, a part of which is the Cowboy Poetry Collection. The Stewart Library at Weber State University in Ogden ( 30 minutes north) has the art and papers of Paul Bransom and the Roser Autograph Collection of European royalty, authors, actors, and other celebrities from the 14th to the 20th centuries.

Situated a few blocks east of downtown Salt Lake on a bench overlooking the city is the University of Utah whose Marriott Library is a major research center of the Intermountain West. Some of its outstanding collections include the Middle East Library, the third largest in North America, containing books, monographs, and periodicals written in the major languages of the Middle East-Arabic, Hebrew, Persian, Ottoman Turkish, and modern Turkish-a as well as Western languages. Its special collections of books and manuscripts on Utah and the West document the history of Indians, early settlers, water, range cattle, reclamation, the pluralistic religious and cultural histories, and Overland Travel literature and North American Indians, including a majority of the books listed in H.R. Wagner's The Plains and the Rockies.
The Harold B. Lee Library at Brigham Young University in Provo (45 minutes south) has the largest collection of books and manuscripts on Mormon Americana in the world except for that in the LDS Church History Library in Salt Lake City. It also has an outstanding collection of rare books on the history of printing from the famous early printing houses of Europe, including 450 incunabula and many books from the presses of Aldus Manutius of Venice and the Etienne family and Simon de Colines of Paris. Its Arts and Communications Archives includes significant collections on filmmaking such as the papers of Cecil B. DeMille, Max Steiner, Hugo Friedhofer, Merian Cooper, Howard Hawks, James Stewart, Dean Jagger, Andy Devine, Argosy Productions, and Republic Pictures Music Archives.

Also of interest here is the new state-of-the-art listening system in the Library Learning Resource Center. Patrons now have full control from their individual carrels of the compact disc players, cassette decks, turntables, and open-reel decks available.

Join one of the planned library tours or come a day early or stay a day longer and visit one of the other libraries. Do your own genealogical or other research while you are here. Let our Utah libraries and librarians show you some of our Western hospitality and friendly service.

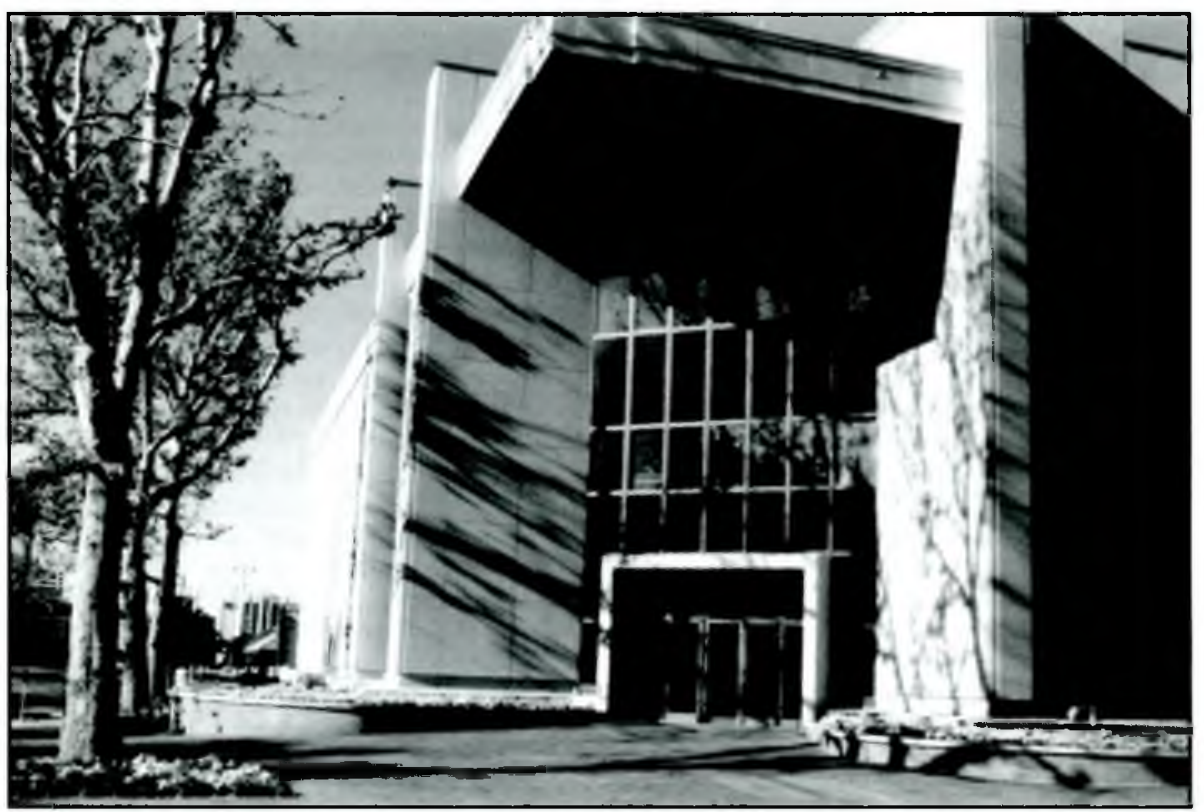

The Church of Latter Day Saints Family History Library in Salt Lake City is the world's largest repository of genealogical information. 


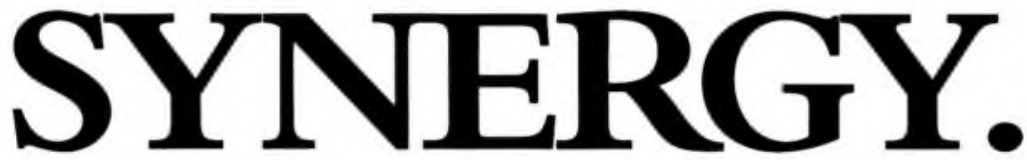

\section{To libraries worldwide, we are much more than the sum of our parts.}
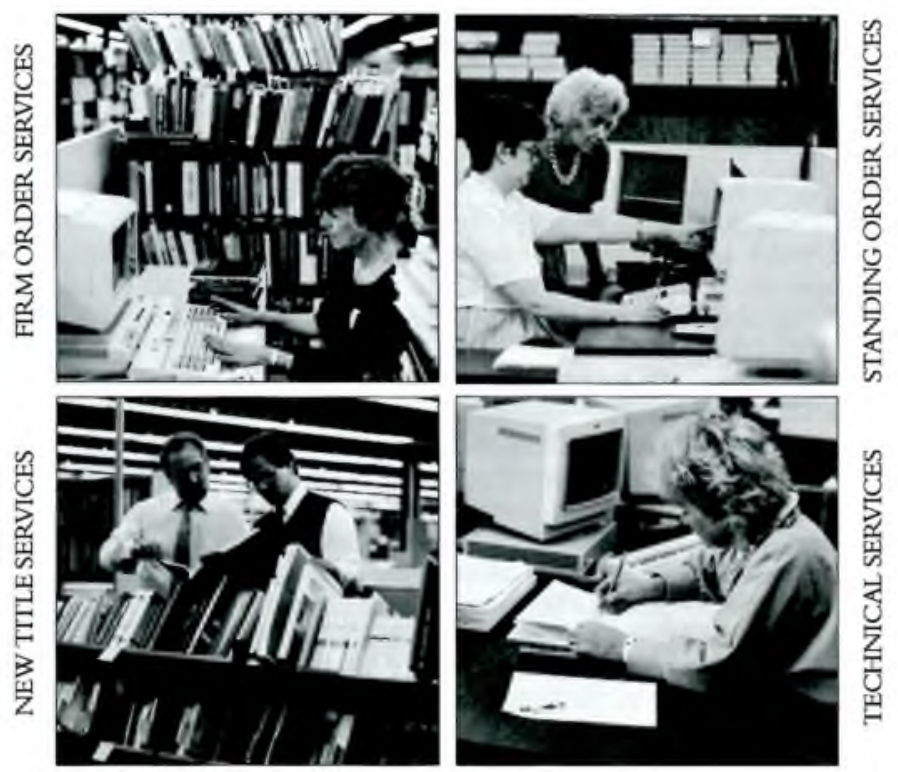

Why do leading academic, research and public libraries rely on Blackwell

North America? We could give a lengthy list. Our people.

Our technology. Our many services tailored precisely to library needs.

And our affiliation with B.H. Blackwell of Oxford, England.

But in reality, you rely on us because we embody the best of the

booksellers' tradition. Books and libraries are our business.

\section{BLACKWELL \\ NORTH AMERICA, INC.}

Part of a proud bookselling tradition dating from 1879 .

Lake Oswego, Oregon • Blackwood, New Jersey

Toll free $1-800-547-6426$ 